\title{
Perbandingan Visual Analogue Scale antara Pemberian Analgetik Asam Mefenamat, Paracetamol dan Ibuprofen Peroral Sebelum Sirkumsisi
}

\author{
Agussalim Ali ${ }^{1}$, Zida Maulina ${ }^{1}$, Raja Al Fath ${ }^{1}$, Muh. Zainsa Asfar ${ }^{2}$ \\ ${ }^{1}$ Fakultas kedokteran Universitas Halu Oleo, Kendari \\ ${ }^{2}$ Program Studi Kedokteran FK UHO, Kendari
}

Corresponding Author e-mail: agusanestesi0508@gmail.com

\begin{abstract}
ABSTRAK
Latar belakang: Nyeri akibat operasi merupakan keadaan yang sangat dikuatirkan oleh pasien sebelum menjalani operasi. Warfield dan Kahn melaporkan 57\% dari pasien yang akan dioperasi menaruh perhatian yang serius terhadap kekuatiran nyeri pasca operasi dan $80 \%$ dari mereka ternyata mengalami nyeri sedang sampai berat setelah operasi. Dalam sirkusmsisi analgesik yang biasa digunakan yaitu Asam Mefenamat, Paracetamol, dan Ibuprofen. Tujuan: Penelitian ini beetujuan untuk mengetahui perbandingan visual analogue scale (VAS) 1 jam setelah sirkumsisi (T1), 2 jam setelah sirkumsisi (T2) dan 3 jam setelah sirkumsisi (T3) antara pasien dengan pemberian analgetik asam mefenamat, paracetamol, dan ibuprofen peroral pre sirkumsisi. Metode: Jenis penelitian ini termasuk penelitian quasi-experimental dengan model posttest design only yang dilakukan di wilayah Kec. Abuki. Jumlah sampel pada penelitian ini adalah 30 sampel, yang terdiri dari 10 sampel asam mefenamat, 10 sampel paracetamol, dan 10 sampel ibuprofen. Penelitan ini dianalisis menggunakan SPSS dengan uji kruskal-wallis. Hasil: Pada T1 menunjukan bahwa terdapat perbedaan rata - rata pada tiap kelompok pemberian obat. Asam mefenamat memiliki nilai rata rata VAS 2,50, paracetamol 3.00 dan ibuprofen 2,30 dengan p-value 0,018. Pada T2 rata - rata VAS yaitu asam mefenamat 4,30, paracetamol 4,70 dan ibuprofen 4,10 dengan p-value 0,252. Pada T3 rata - rata VAS tiap kelempok obat yaitu, asam mefenamat 7,00, paracetamol 7,50, dan ibuprofen 6,40 dengan p-value 0,003. Simpulan: Terdapat perbedaan rata-rata VAS pada T1, T2 dan T3, dengan kelompok terendah yaitu pada kelompok ibuprofen.
\end{abstract}

Kata kunci : Asam mefenamat, Ibuprofen, Paracetamol, Sirkumsisi, Visual analogue scale.

PENDAHULUAN

Sirkumsisi (khitanan) adalah membuang preputium penis sehingga glans penis menjadi terbuka. Tindakan ini merupakan tindakan bedah minor yang paling banyak dikerjakan diseluruh dunia, baik dikerjakan oleh dokter, paramedis, ataupun oleh dukun sunat. Sirkumsisi dilakukan seorang pria guna menjaga kebersihan dan kesehatan organ genitalnya. Belakangan ini sirkumsisi hanya dipandang sebagai suatu kewajiban yang dilakukan oleh sekelompok orang demi menjalankan ritual budaya dan keagamaannya (Sibuea, 2017).

Nyeri akibat operasi, merupakan keadaan yang sangat dikuatirkan oleh pasien sebelum menjalani operasi. Warfield dan Kahn melaporkan 57\% dari pasien yang akan dioperasi menaruh perhatian yang serius terhadap kekuatiran nyeri pasca operasi dan $80 \%$ dari mereka ternyata mengalami nyeri sedang sampai berat setelah operasi (Gayatri, 2008).

Sirkumsisi akan menimbulkan nyeri karena perlukaan pada kulit penis yang disebabkan terjadinya peradangan. Peradangan yang terjadi pada jaringan yang lokal melibatkan banyak mediator kimia. Peradangan tersebut adalah respon fisiologis tubuh dan merupakan respon imun non spesifik. Menurut International Association for the Study of Pain (IASP), nyeri didefenisikan sebagai pengalaman sensoris dan emosional yang tidak menyenangkan terkait dengan kerusakan jaringan atau 
potensi yang akan mengakibatkan kerusakan jaringan (Pramono, 2018).

Penatalaksanaan atau terapi nyeri pada sirkumsisi dapat dilakukan dengan penggunaan anastesi lokal maupun penggunaan analgesik. Pemberian analgetik opioid atau analgetik non opioid dan anastesi lokal sebelum operasi dapat mengurangi efek spinal dari serapan nosiseptif yang diinduksi serabut-C yang berhubungan dengan insisi, dan dengan demikian akan mengurangi intensitas nyeri pasca operasi, yang kemudian metode tersebut dikenal dengan nama pre-emtive analgesia (Clark, 2014.)

Intensitas nyeri pada anak maupun pada dewasa dapat diukur dengan menggunakan salah satu metode yaitu Visual Analogue Scale (VAS). Metode ini menggunakan garis sepanjang $10 \mathrm{~cm}$ yang menggambarkan keadaan tidak nyeri sampai nyeri sangat hebat. Keuntungan menggunakan metode ini adalah sensitif untuk mengetahui perubahan intensitas nyeri, mudah dimengerti dan dikerjakan, dan dapat digunakan dalam berbagai kondisi klinis (Jaury dkk, 2014).

Beradasarkan uraian latar belakang diatas dan dilandasi oleh teori yang dikemukan oleh Loise Clark tentang metode Pre-emtive Analgesia, maka peneliti tertarik untuk membandingan nilai VAS antara pemberian analgetik Asm Mefenamat, Paracetamol, dan Ibu Profen Per Oral Pre sirkumsisi

\section{METODE PENELITIAN}

Penelitian ini merupakan penelitian quasi-experimental untuk mengetahui perbandingan nyeri pada pemberian analgetik asam mefenamat, paracetamol, dan ibuprofen peroral pre sirkumsisi. Desain penelitian yang digunakan dalam penelitian ini adalah posttest design only. Penelitian ini dilaksanakan pada bulan Juni 2019 yang bertempat di Kec. Abuki Kab. Konawe. Jumlah sampel pada penelitian ini adalah 30 sampel yang terdiri dari 10 sampel asam mefenamat, 10 sampel paracetamol, dan 10 sampel ibuprofen, yang diambil menggunakan teknik purposive sampling. Penelitian ini dianalisis dengan menggunakan uji Kruskal Wallis

\section{Kelayakan Etik}

Penelitian ini telah mendapatkan persetujuan etik dari Komisi Etik Penelitian Kesehatan Lembaga Penelitian dan Pengabdian Kepada Masyarakat Universitas Halu Oleo dengan nomor 954/UN29.20/PPM/2019.

\section{HASIL PENELITIAN}

Berdasarkan tabel 1 dapat diketahui bahwa pada pengukuran T1 (1 jam setelah sirkumsisi) terdapat perbedaan rata - rata nilai VAS yaitu yang tertinggi adalah paracetamol 3,00 dengan nilai minimum 2 dan maximum 4, asam mefenamat 2,50 dengan nilai minimum 2 dan maximum 3 , dan yang terendah yaitu ibuprofen 2,30 dengan nilai minimum 2 dan maximum 3 . Pada pengukuran T2 (2 jam setelah sirkumsisi) nilai VAS tertinggi yaitu paracetamol 4,70 dengan nilai minimum 4 dan maximum 6, asam mefenamat 4,30 dengan nilai minimum 3 dan maximum 6 , dan yang terendah yaitu ibuprofen 4,10 dengan nilai minimum 3 dan maximum 5 . Sedangkan pada pengukuran T3 (3 jam setelah sirkumsisi) nilai VAS tertinggi yaitu paracetamol 7,50 dengan nilai minimum 7 dan maximum 8, asam mefenamat 7,00 dengan nilai minimum 6 dan maximum 8 , dan yang terendah yaitu ibuprofen 6,40 dengan nilai minimum 6 dan maximum 7 . 
Tabel 1. Perbedaan nilai rata - rata VAS pada tiap pemberian anlgetik di pengukuran T1, T2, dan T3

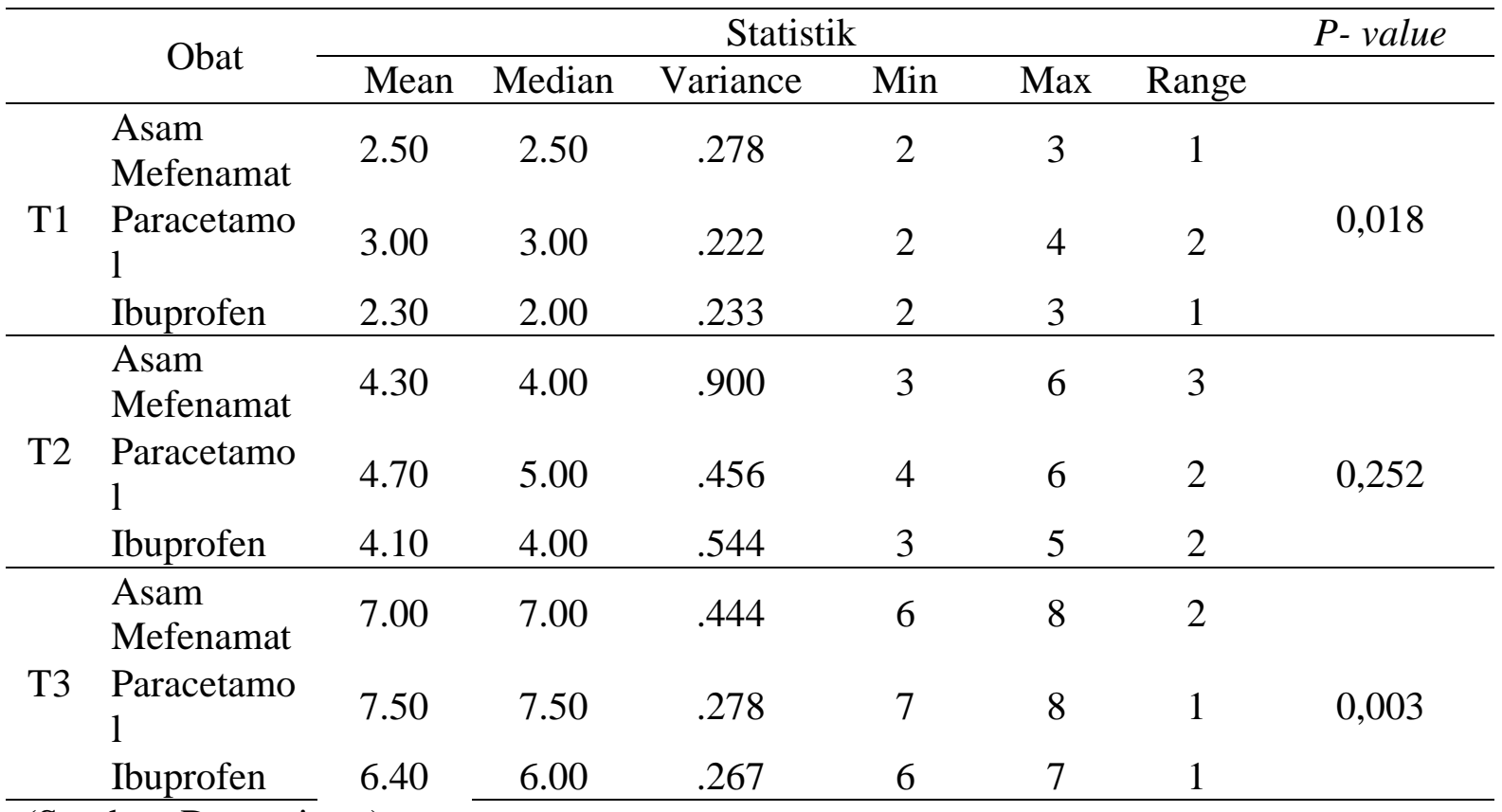

(Sumber: Data primer)

\section{PEMBAHASAN}

\section{Perbandingan nilai VAS T1}

Berdasarkan hasil uji statistic didapatkan $\mathrm{p}$ value yaitu 0,018 yang berarti terdapat perbadaan rata -rata yang bermakna antara analgetik asam mefenamat, paracetamol, dan ibuprofen pada 1 jamsetelah sirkumsisi, dengan kelompok VAS terendah yaitu ibuprofen. Ibuprofen efektif digunakan untuk mengurangi nyeri pasca operasi dibuktikan dalam kasus studi terbaru penggunaan NSIDS, missalnya pada operasi tonsilektomi sangat disarankan diberikan pada anak-anak untuk mengontrol perdarahan dan pengendalian nyeri pasca operasi, sehingga ibuprofen aman dan efektif diberikan pada anak (Swanso dkk., 2018).

\section{Perbandingan nilai VAS T2}

Pada T2 terdapat perbedaan rata rata VAS yaitu asam mefenamat 4.30, paracetamol 4.70 dan yang terendah yaitu pada kelompok ibuprofen 4.10. Namun, perebedaan tersebut tidak signifikan secara statistik karena nilai $p$-value $>0,05$ yaitu 0,252 . Hal tersebut diakibatkan karena pada nilai rata - rata VAS T2 tiap kelompok obat tidak memberikan perbedaan yang cukup signifikan dibandingkan rata - rata nilai VAS di T1 dan T3.

\section{Perbandingan nilai VAS T3}

Berdasarkan hasil uji sattistik didapatkan p-value 0,003, yang berarti terdapat perbedaan rata - rata yang bermakna pada 3 jam setelah sirkumsisi, dengan rata - rata VAS terendah 6.40 yaitu pada kelompok ibuprofen. Menurut penelitian yang dilakukan oleh (Gazal dan Samadani, 2017) menjelaskan bahwa sampai dengan 6 jam post operasi ibuprofen lebih efektif menurunkan nyeri dibandingkan dengan paracetamol. Pemberian dosis Ibuprofen peroral $200 \mathrm{mg}$ dapat mempunyai efek analgetik 4-6 jam, sehingga pada waktu 3 jam setelah sirkumsisi ibuprofen masih 
bisa mengurangi intensitas nyeri (Ayatulaila, 2016).

Berdasarkan uraian diatas dapat disimpulkan bahwa terdapat perbedaan rata - rata nilai VAS pada tiap kelompok obat, baik pada pengukuran T1, T2, maupun T3. Kelompok obat yang memiliki rata-rata VAS terendah yaitu Ibuprofen, hal ini menandakan bahwa ibuprofen mampu mengurangi intensitas nyeri pada pasien sirkumsisi. Penelitian ini sejalan dengan penelitian yang dilakukan oleh (Anggara, 2016) yang membandingkan antara pemberian paracetamol pre sirkumsisi dan ibuprofen post sirkumsisi, yang menunjukkan hasil bahwa pemberian ibuprofen lebih efektif mengurangi intensitas nyeri dibandingkan dengan paracetamol. Paracetamol kurang efektif untuk mengurangi nyeri karena obat ini adalah penghambat prostaglandin yang lemah pada jaringan perifer atau efeknya kurang terhadap siklooksigenase jaringan perifer dan mempunyai sedikit atau tidak mempunyai aktivitas anti-inflamasi, inilah yang menyebabkan paracetamol hanya menghilangkan atau mengurangi rasa nyeri ringan (Anggara 2016).

Menurut (Syarif dkk, 2012) asam mefenamat dapat digunakan sebagai analgetik dan sebagai anti inflmasi namun penggunaan asam mefenamat kurang efektif dibandingkan dengan aspirin, yang mepunyai efek anlgetik sama seperti ibuprofen.

\section{SIMPULAN}

Berdasarkan hasil penelitian dapat disimpulkan bahwa pada $\mathrm{T}$ !, T2, dan T3 kelempok obat yang menunjukkan nilai VAS terendah yaitu kelompok ibuprofen

\section{DAFTAR PUSTAKA}

Anggara, Cornel. 2016. Perbandingan Efektivitas Pemberian Parasetamol Pre Sirkumsisi Terhadap Rasa Nyeri Setelah Sirkumsisi. Skripsi. Fakultas Kedokteran dan Ilmu Kesehatan Universitas Muhammadiyah Yogyakarta

Ayatulaila, I. 2016. Evaluasi Penggunaan Analgetik Dan Efektivitasnya Pada Pasien Kanker Organ Reproduksi Wanita Di Rumah Sakit X Tahun 2015. Skripsi. Programstudi Sarjana Farmasi. Universitas Muhamadiyah Surakarta.

Clark, Loise dkk. .2014. Pre-emptive or preventive analgesia - lessons from the human literature. Association of Veterinary Anaesthetists and the American College of Veterinary Anesthesia and Analgesia.

Gayatri, Astrid. 2008. Pengaruh Analgesia Akupuntur Frekuensi Kombinasi Terhadap Onset Nyeri Pasien Pasca Operasi Lengan Bawah Tertutup. Skripsi. Fakultas Kedokeran Universitas Muhamadiyah Surakarta.

Gazal, G dan Samadani, KH. 2017. Comparison of paracetamol, ibuprofen, and diclofenac potassium for pain relief following dental extractions and deep cavity preparations. Saudi Med

Jaury, Francis Daniel dkk. 2014. Gambaran nilai VAS ( Visual Analogue Scale) pasca bedah seksio sesar pada penderita yang diberkan tramadol. Bagian Anastesiologi Dan Terapi Intensif Fakultas Kedokteran Universitas Samratulangi Manado. Manado

Pramono, Ardi dkk. 2018. Preemptive analgesic with paracetamol and 
tramadol analgesics in pediatric circumcision Jurnal Kedokteran dan kesehatan Indonesia.. Department of Anesthesiology, Faculty of Medicine and Health Sciences Universitas Muhammadiyah Yogyakarta

Sibuea, Bima Andika. 2017. Pengetahuan dan Sikap Siswa tentang Sunat (Sirkumsisi) di SMA Raksana Medan Tahun 2017. Skripsi. Fakultas Kesehatan Masyarajat Universitas Sumatra Utara. Medan.

Syarif. Amir. dkk. 2012. Farmakologi dan Terapi Edisi 5. Departemen Farmakologi dan terapeutik fakultas kedokteran Indonesia. 240.

Swanso,R., Shubart,J., dan Car, M. 2018. Association of ibuprofen use with post-tonsillectomy bleeding in older children. Am J Otolaryngol. College of Medicine, The Pennsylvania State University, College of Medicine, Hershey, PA, United State 